\title{
Summer Diet of Two White-tailed Deer, Odocoileus virginianus, Populations Living at Low and High Density in Southern Québec
}

\author{
Claude Daigle $^{1,4}$, Michel Crête ${ }^{1,3}$, Louis Lesage ${ }^{2,4}$, Jean-Pierre Ouellet ${ }^{3}$, and Jean Huot ${ }^{2}$ \\ ${ }^{1}$ Ministère des Ressources naturelles, de la Faune et des Parcs du Québec, Direction du développement de la faune, 675 \\ boul. René-Lévesque est, BP 92, Québec, Québec G1R 5V7 Canada; corresponding author \\ ${ }^{2}$ Département de biologie et Centre d'études nordiques, Pavillon Vachon, Université Laval, Sainte-Foy, Québec G1K 7P4 \\ Canada \\ ${ }^{3}$ Département de biologie et Centre d'études nordiques, Université du Québec à Rimouski, 300 Allée des Ursulines, Rimouski, \\ Québec G5L 3A1 Canada \\ ${ }^{4}$ Present address: Environment Canada, Region de Québec, Service Canadien de la faune, 1141 Route de L'Église, C.P. 10100, \\ Ste-Foy, Québec G1V 4H5 Canada
}

Daigle, Claude, Michel Crête, Louis Lesage, Jean-Pierre Ouellet, and Jean Huot. 2004. Summer diet of two White-tailed Deer, Odocoileus virginianus, populations living at low and high density in southern Québec. Canadian Field-Naturalist 118(3): 360-367.

We investigated summer diets of two White-tailed Deer (Odocoileus virginianus) populations through rumen content analyses. Samples from 93 deer were collected in a low density, LD (1 deer $\left./ \mathrm{km}^{2}\right)$ and a high density, HD (14 deer $\left./ \mathrm{km}^{2}\right)$ area of southern Québec during the growing seasons of 1997 and 1998. Availability of preferred forage in forests was greater in LD than in $\mathrm{HD}$, whereas agriculture covered a larger proportion of the area in HD than LD. Rumen composition differed between the two populations. Deer from HD consumed less forbs and leaves of shrubs and trees than did LD deer, whereas they consumed more fruits, grasses and farm crops. The rarity in HD rumens of food items common in LD, as well as in many parts of the White-tailed Deer range (i.e., Lilliacae), indicated that deer could not compensate for the rarity of preferred forest forage by increasing foraging time and had to feed on cultivated crops. Rumen contents of LD deer had a higher level of cell solubles and lignin, which reflected their greater reliance on quality forage growing in forests. Feeding habits and forage quality can explain why deer body size decreased in HD between the 1970s and 1990s whereas LD deer remained large.

Key Words: White-tailed Deer, Odocoileus virginianus, diet, density, forest, agriculture, plant, Québec, Canada

Nous avons examiné le régime alimentaire estival de deux populations de cerf de Virginie (Odocoileus virginianus) par l'analyse du contenu des rumens. Des échantillons ont été prélevés sur 93 cerfs provenant d'un secteur à faible densité de cerfs, LD, $\left(1\right.$ cerf $\left./ \mathrm{km}^{2}\right)$ et d'un secteur à haute densité, $\mathrm{HD},\left(14\right.$ cerfs $\left./ \mathrm{km}^{2}\right)$ du sud du Québec durant la saison de croissance des végétaux de 1997 et 1998. La disponibilité des aliments forestiers préférés des cerfs était plus grande dans LD que dans HD alors que la proportion du territoire agricole était supérieure dans HD. La composition des rumens des cerfs de chacune des régions différait. Les cerfs de HD ont consommé de moins grandes proportions de plantes herbacées et de feuilles d'arbustes et d'arbres que ceux du secteur LD, mais de plus grandes proportions de fruits, de graminées et de plantes agricoles. La rareté dans les rumens du secteur HD d'aliments communs dans ceux du secteur LD et dans plusieurs autres régions de l'aire de répartition du cerf (e.g., Lilliacae), indique que les cerfs du secteur HD ne pouvaient compenser pour la rareté de leurs aliments préférés par un accroissement de la durée de la quête alimentaire, et qu'ils devaient consommer des plantes agricoles. Les cerfs de LD ont mangé des aliments contenant plus de solubles cellulaires et de lignine que ceux de HD, ce qui reflète une consommation de plantes forestières de bonne qualité. Le régime alimentaire et la qualité de la nourriture peuvent expliquer pourquoi la taille des cerfs de HD a diminué entre les années 1970 et 1990 alors que celle des cerfs de LD est demeurée grande.

White-tailed Deer, Odocoileus virginianus, are selective feeders and although they ingest a wide variety of plants, only a few taxa make up large proportions of their diet (Johnson et al. 1995; Healy 1971; Korschgen et al. 1980; McCaffery et al. 1974). Plant phenology influences their diet; forbs and leaves of deciduous woody plants are common food items in spring and summer, and fruits become major components of the autumn diet. White-tailed Deer also consume mushrooms in natural ecosystems (Crawford 1982; Johnson et al. 1995; Korschgen et al. 1980; Short 1971; Skinner and Telfer 1974), whereas farm crops can be major food sources in agricultural landscapes (Nixon et al. 1991). During winter, White-tailed Deer switch to twigs of both deciduous and evergreen woody plants and, where snow cover allows access, they also use grasses and farm crops left after harvest (Johnson et al. 1995; McCaffery et al. 1974; McCullough 1985; Nixon et al. 1991; Skinner and Telfer 1974).

Forage competition results in consumption of food of reduced quality or availability, which lengthens ingestion and digestion. At high density, forage competition can modify feeding habits of ungulates, in particular for small, selective species (Kie and Bowyer 1999) and reduce body size in cervids (Ashley et al. 1998; Crête et al. 1993; Hjeljord and Histol 1999; Lesage et al. 2001). In mid-latitude deer, forage competition during the growing season likely determines adult body 
size because growth and replenishment of body reserves occur during this period of the year (Hjeljord and Histol 1999; Lesage et al. 2001; Boucher 2004).

On the south shore of the St. Lawrence River in Québec, the carrying capacity of the deer range decreases northward because suitable forest stands for wintering become increasingly rare with increasing winter severity (Boucher 2004). Density averaged $\approx 1$ deer/ $\mathrm{km}^{2}$ in northernmost hunting zones of Québec whereas it locally exceeded $30 \mathrm{deer} / \mathrm{km}^{2}$ in southern zones after populations erupted due to mild winters and a conservative hunting regime. Forage competition in winter regulates deer numbers in the absence of Grey Wolves (Canis lupus) and under conservative hunting regime (Dumont et al. 2000), but agriculture can help deer to survive winter by providing some food during the dormant season (Rouleau et al. 2002a). In recent decades, browsing pressure exhibited a pronounced gradient on the south shore of the St. Lawrence River, which resulted in a scarcity of preferred summer forage in southern vs. northern zones (Rouleau et al. 2002a). Vegetation sampling throughout the deer range in Québec showed a general pattern of negative relationship between deer density on one hand, and preferred forest forage and deer size on the other (Boucher 2004). Deer living at low density tended to avoid cultivated fields (Lesage et al. 2002) and reached the largest size among Québec deer (Lesage et al. 2001).

We studied the summer feeding habits of Whitetailed Deer in two areas which differed markedly with respect to deer density, forage availability, importance of agriculture, and winter severity. The objective of this study was to compare composition and quality of summer diets of these two White-tailed Deer populations. We anticipated that preferred forage of deer living at low density would be less abundant in rumens of deer living at high density and that the low density population would consume forage of higher quality due to relaxed forage competition during summer.

\section{Study Area}

Samples were collected in a low-density area (LD) and a high-density area (HD) (Figure 1). The LD study area is located in a transition zone between northern hardwood forests and boreal forests (Rowe 1972*). Among trees, Balsam Fir (Abies balsamea), White Spruce (Picea glauca), Eastern White Cedar (Thuja occidentalis), Trembling Aspen (Populus tremuloides), and Yellow Birch (Betula alleghaniensis) dominate (Lamoureux 1994*). Commercial logging has been intensive in this region and the spruce budworm (Choristoneura fumiferana) adversely impacted fir and spruce stands in the late 1970s. Agriculture represents about $10 \%$ of the land use in the study area and hay; alfalfa (Medicago sativa), cultivated and upgraded pastures, oat (Avena sativa), and barley (Hordeum vulgare) cover most cultivated fields. The grow- ing season averages 160 days (Wilson 1971*) and snow cover often exceeds $50 \mathrm{~cm}$ for more than 50 days. Deer density was estimated through double-count aerial surveys (Potvin et al. 1992) and averaged $1.1 \mathrm{deer} / \mathrm{km}^{2}$ in summer 1998 (Lamoureux and Pelletier 2000*).

Northern hardwood forests cover most of the HD study area. Commercial logging has affected mainly coniferous stands on small areas due to land ownership and forest composition (Gosselin 1994*). Most common tree species include Sugar Maple (Acer saccharum), Red Maple (Acer rubrum), Yellow Birch, American Beech (Fagus grandifolia), White Ash (Fraxinus americana), Balsam Fir, Hemlock (Tsuga canadensis), Eastern White Cedar, and White Spruce. Forests have been cleared for agriculture throughout the region. They have progressively grown back on abandoned farms; and introduced plants such as apple trees (Malus pumila) are common in today's forests. Agriculture now covers about 23\% of the area. Hay, corn (Zea mays), uncultivated pastures, cultivated and upgraded pastures, and alfalfa dominate cultivated fields. The growing season averages 190 days and snow cover rarely exceeds $50 \mathrm{~cm}$. Deer density averaged 14.1 deer $/ \mathrm{km}^{2}$ in summer 1996 (Dicaire 1999*); locally it may exceed $30 \mathrm{deer} / \mathrm{km}^{2}$.

\section{Methods}

Forage composition - We collected rumen samples from road kills during the growing season (13 May 2 November 1997 and 1998). Rumen samples were generally collected within 3 days after collision (maximum 5 days), provided that identifiable forage fragments remained. Rumen content was hand mixed and two one-litre samples were extracted. The first litre was frozen for forage identification and the other preserved in $4 \%$ formalin for chemical analysis. At the laboratory, frozen samples were thawed and washed through a $7.9 \mathrm{~mm}$ and a $4.0 \mathrm{~mm}$ mesh size sieve (Crête et al. 1990; Gauthier et al. 1989). About $50 \mathrm{ml}$ of the particles kept by the $4.0 \mathrm{~mm}$ sieve were spread into a $20 \times 50 \mathrm{~cm}$ sampling tray (Chamrad and Box 1964) and covered with $1 \mathrm{~cm}$ of water. One hundred particles were systematically selected by point sampling (Crête et al. 1990) and identified through macroscopic and microscopic $(10-25 \times)$ examination to family, genus or species whenever possible. Reference plant samples served for comparison during the identification process. Samples were grouped by taxon and their volume measured by water displacement $( \pm 0.25 \mathrm{~mL})$. Plants were grouped into eight categories for statistical analyses: graminoids (Graminae and Cyperacae), farm crops, forbs (without flowers or fruits), leaves of shrubs and trees, wild flowers, wild fruits, mushrooms, and unknown.

Forage quality - We reasoned that rumens of deer consuming poor quality forage would contain fewer nutrients with rapid assimilation and more nutrients with slow digestibility than counterparts feeding on 
better quality forage. Poor quality forage could also include more secondary compounds slowing or inhibiting digestion. We measured cell solubles, lignin, and phenolics as proxy for rapid digestibility, slow digestibility and defensive compounds. We also determined nitrogen $(\mathrm{N})$ content because it proved to be a good indicator of summer diet quality in Caribou (Rangifer tarandus) (Crête et al. 1990). We used the detergent method (Gauthier et al. 1989; Goering and Van Soest 1970) to measure cell solubles (1-NDF) and acid detergent lignin (ADL) (Mould and Robbins 1982). Cell solubles are highly digestible whereas lignin is largely not (Robbins 1993: 251, 294). Total nitrogen content $(\mathrm{N})$ was measured with an automated Macro-Kjeldahl analyzer and total phenolic content was determined by a calorimetric method using the Folin-Ciocalteu reagent (Marigo 1973; Sauvesry et al. 1991). Proteins are also highly digestible (Robbins 1993: 294) whereas phenolics includes 8000 substances, of which tannins are known for reducing protein digestion (Robbins 1993: 300). Some samples could not be analysed due to inadequate quantities. All analyses were duplicated or triplicated whenever a difference of more than $5 \%$ was found between the first two measurements. The average of the two closest estimates served as results.

Forage availability - We estimated forage availability during a companion study in the same study areas (Rouleau et al. 2002a). We measured forage biomass between the ground and $1.5 \mathrm{~m}$ in height at sites used by radio-collared deer in the two areas throughout the growing season with the help of 11 linear regression models. Vertical and lateral plant coverage over 2-m transects served as dependant variables in regression models to predict plant biomass by species (Rouleau et al. 2002b).

Data analysis - In a first step, we determined whether sex (for deer $>1$ year old) and age (fawns vs. $>1$ year old) influenced forage composition or quality as summer progressed using MANOVA. We restricted the analysis to the HD area because our samples from deer with known sex and age were too small in the LD area. Analyses were performed on sex and age with respect to months, including sex by month, and age by month interactions.

We used ANOVA for contrasting forage composition and quality between the two study areas. We pooled months two by two for this analysis to ensure adequate sample size for each period in both regions. ANOVA were followed by pairwise protected LSD tests (PROC GLM, PDIFF option, SAS Institute Inc. 1988). For all analyses, we ensured that residuals were normally distributed (Shapiro-Wilk test) and homogenous (visual inspection of the plot). For forage composition, we carried out ANOVA on ranks because we could not normalise residuals. We estimated means and their standard error with the LSMEANS statement (SAS Institute Inc. 1988).

\section{Results}

Rumen samples were collected from 93 deer (HD 68 / LD 25): 64 adults, 11 fawns, and 18 of unknown age. On a volumetric basis, $80 \%$ of the particles examined could be identified to 68 food items. Males and females showed no overall differences in the food items they selected in the HD area when considering forage categories $(\mathrm{F}=0.52 ; \mathrm{df}=6,38 ; \mathrm{P}=0.79)$ or diet quality $(\mathrm{F}=0.21 ; \mathrm{df}=5,22 ; \mathrm{P}=0.95)$, without sex $\times$ age interaction for composition $(\mathrm{F}=0.77$; $\mathrm{df}=24,134 ; \mathrm{P}=0.76)$ and quality $(\mathrm{F}=0.69 ; \mathrm{df}=20$, $74 ; \mathrm{P}=0.83)$. Neither did age influence forage composition $(\mathrm{F}=0.26 ; \mathrm{df}=6,49 ; \mathrm{P}=0.95)$ or quality $(\mathrm{F}=2.27 ; \mathrm{df}=5,28 ; \mathrm{P}=0.08)$, nor did it interact with month on a composition $(\mathrm{F}=2.31 ; \mathrm{df}=6,53 ; \mathrm{P}=0.05)$ or quality $(\mathrm{F}=1.43 ; \mathrm{df}=5,28 ; \mathrm{P}=0.24)$ basis. Given these results, we did not take into account age and sex in subsequent analyses.

Diet composition - Rumen contents differed between the two study areas (Figure 2). In spring, rumens contained no farm crops in LD but $13 \%$ in $\mathrm{HD}(\mathrm{P}=0.03)$. Grasses $(P=0.08)$ and flowers $(P=0.07)$ also tended to be more important food items in HD than in LD. Conversely, forbs $(\mathrm{P}=0.04)$ and leaves of shrubs and trees $(P=0.12)$ accounted for a larger volume in $\mathrm{LD}$ samples. Diets during July-August were more comparable; the only significant difference was for forbs: $32 \%$ in $\mathrm{LD}$ vs. $7 \%$ in $\mathrm{HD}(\mathrm{P}=0.01)$. Rumens collected during September and October contained more mushrooms $(\mathrm{P}<0.01)$ and leaves of shrubs and trees $(\mathrm{P}=0.08)$ in LD, whereas those collected in HD included more fruits $(\mathrm{P}<0.01)$ and grasses $(\mathrm{P}=0.08)$.

Differences between the two study areas were more striking when considering taxa for the whole growing season (Table 1). For this comparison, we eliminated fruits, mostly apples, because they were almost restricted to HD and their more three-dimensional shape contrasting with that of most other two-dimensional plant tissues resulted in exceptionally large volume. Excluding fruits, 19 food items each accounted for more than $1 \%$ of the rumen volume in $\mathrm{LD}$, summing up to $95 \%$ of volume, compared with 20 food items making up $87 \%$ of rumen content in HD. Forest forbs, such as Yellow Clintonia (Clintonia borealis) and WildLily-of-the-Valley (Maianthemum canadense) were common food items in LD but rare in rumens collected in HD. They were replaced in HD by forbs typical of openings and by farm crops, such as clover (Trifolium sp.) and alfalfa. Mountain Maple (Acer spicatum) and Mountain Ash (Sorbus americana), the most common shrub leaves in rumens collected in $\mathrm{LD}$, were replaced by Red Maple, Choke Cherry (Prunus virginiana), and Sugar Maple in HD; the latter species were also consumed by LD deer, but to a much lesser extent. Finally, apples, the most common item in HD rumens, were found in only one LD sample.

Diet quality - Nitrogen $(\mathrm{F}=0.91 ; \mathrm{df}=1,52 ; \mathrm{P}=0.34)$ and phenolic content $(\mathrm{F}=0.13 ; \mathrm{df}=1,52 ; \mathrm{P}=0.71)$ 


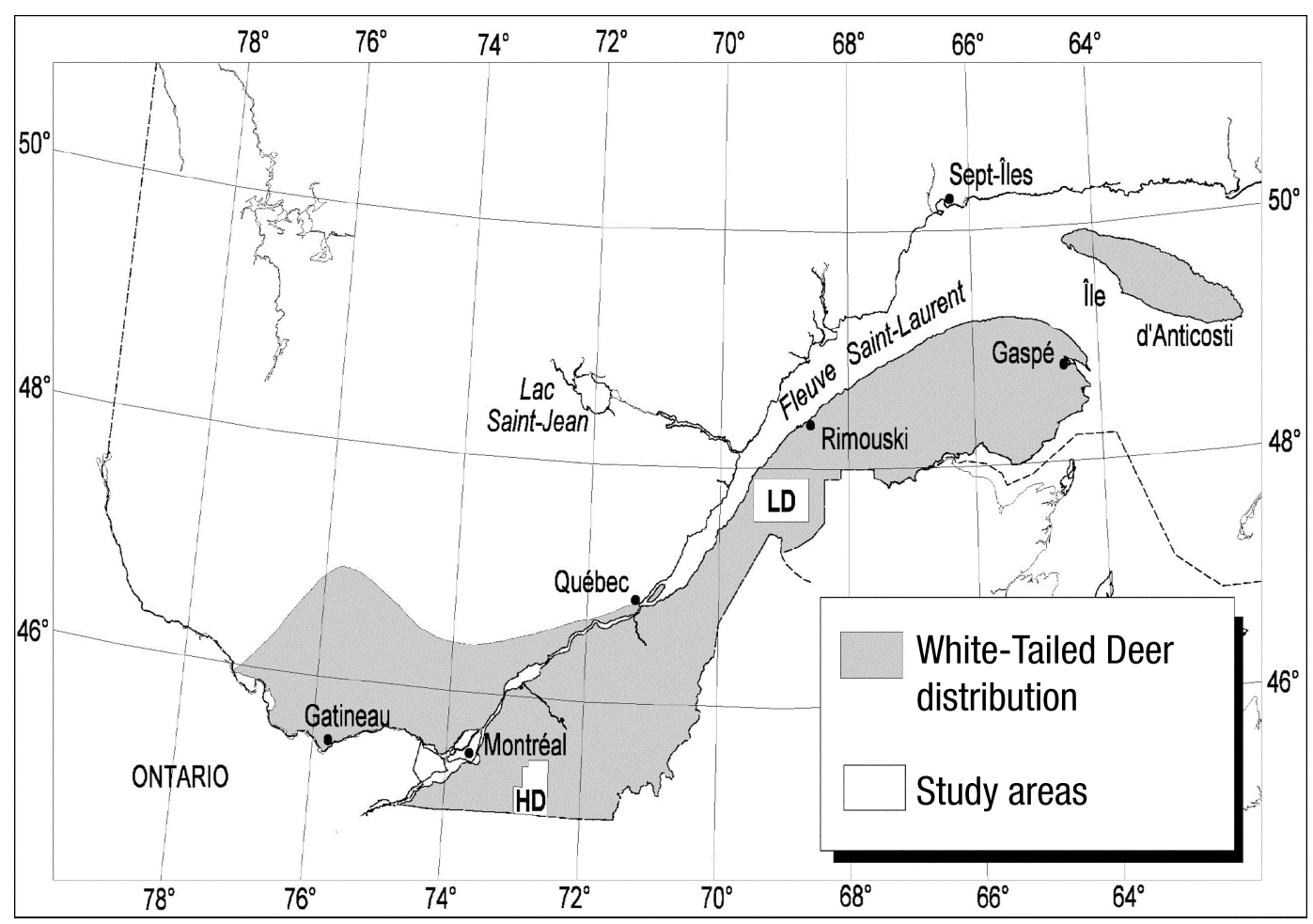

FIGURE 1. White-tailed Deer distribution in Québec and location of the two study areas, low density (LD) and high density (HD).

did not differ between the two areas, with nitrogen remaining stable as the growing season progressed, and phenolic content declining in September-October (Table 2). However, LD rumens contained more cell solubles $(\mathrm{F}=5.66 ; \mathrm{df}=1,69 ; \mathrm{P}=0.02)$ and lignin $(\mathrm{F}$ $=4.68 ; \mathrm{df}=1,69 ; \mathrm{P}=0.03$ ) than those from LD.

\section{Discussion}

Diet composition - Forage availability is reflected in diet composition. Although climate differed between LD and HD, the two regions shared most plant taxa and natural forage species had similar digestibility in both areas throughout the growing season (Lesage et al. 2000). However, biomass of preferred forage species found at sites used by deer was much larger in LD than HD (Rouleau et al. 2002a). Food items which dominated in LD diets remained almost absent from HD rumens. For instance Liliacae, such as Yellow Clintonia and Wild-Lily-of-the-Valley, which White-tailed Deer normally consume in the Northeast (Crawford 1982; Korschgen et al. 1980; McCaffery et al. 1974; Skinner and Telfer 1974; Waller and Alverson 1997) occupied a marginal volume in HD rumens. Liliacae are particularly vulnerable to deer browsing (Crête et al. 2001; Waller and Alverson 1997) and can be used as indi- cators to estimate the impact of White-tailed Deer on plant communities (Balgooyen and Waller 1995). WildLily-of-the-Valley was common in HD in the early 1980s (Guérard and Legris 1984*). At the time of our study, its biomass was 20 times lower in HD than in LD (Rouleau et al. 2002a) and occurred as a marginal food item in the diet of HD deer (Table 1). Although not abundant on a volumetric basis, Wild-Lily-of-theValley occurred in $16 \%$ of the rumens collected in $\mathrm{HD}$, showing that deer were still looking for this species even though its availability was largely reduced. Mountain Maple, which is known to be affected by deer (Balgooyen and Waller 1995), was a common species in HD in the past (Guérard and Legris 1984*), but seemed almost extirpated at the time of our study (Rouleau et al. 2002a). In LD, where natural forage is abundant (Rouleau et al. 2002a), Lesage et al. (2002) found that deer avoided cultivated fields. Our results support their findings and indicate that White-tailed Deer prefer to consume forest forages when they are readily available during the growing season. In HD, where most preferred food items had become scarce (Rouleau et al. 2002a; Boucher 2004), deer switched to other natural forage still persisting (e.g., Red Maple, Choke Cherry and Sugar Maple) and relied on farm 

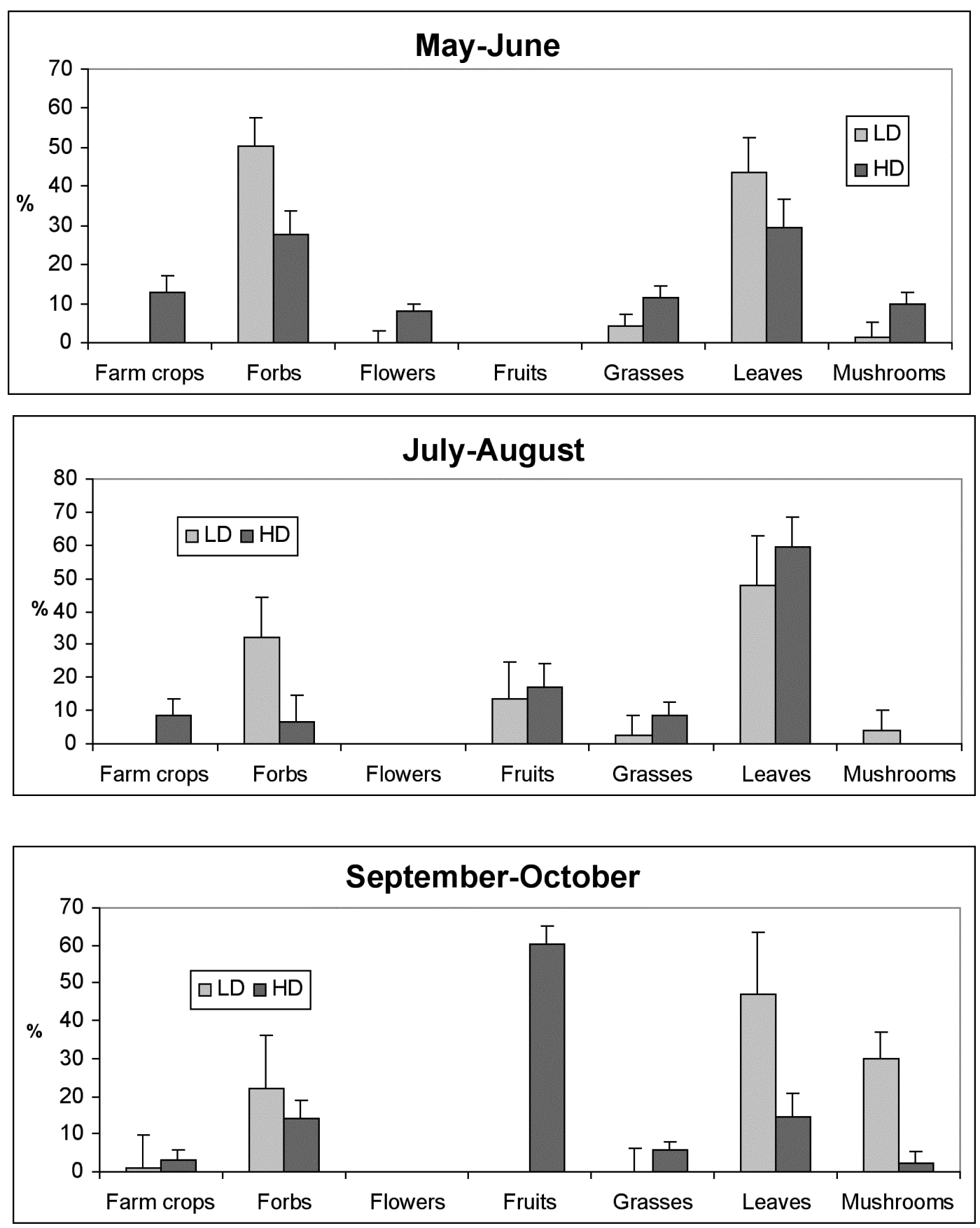

FIGURE 2. Composition ( $\%$ volume \pm SE) of rumen samples collected in a low-density LD $(n=25)$ and a high-density HD $(n=68)$ area of southern Québec during the growing seasons of 1997 and 1998.

crops for a large part of their summer diet. Comparison of forage availability and consumption (Table 1) suggests that Red Maple, Choke Cherry, and Sugar Maple suffered high browsing pressure in HD.
Fruits, mostly apples (90\%), were a major component of the fall diet in HD. Our results support the idea that fruits are important food items where and when they are available (McCaffery et al. 1974; Short 1971; 
TABLE 1. Most common food items (volume $>1 \%$ ) found in White-tailed Deer rumens from a low density LD ( $\mathrm{n}=23)$ and a high density HD area (n=63) of southern Québec during the growing seasons of 1997 and 1998.

\begin{tabular}{|c|c|c|c|c|c|c|c|}
\hline \multirow[b]{2}{*}{ Food items } & \multirow[b]{2}{*}{ Category } & \multicolumn{2}{|c|}{$\%$ volume } & \multicolumn{2}{|c|}{$\%$ occurence } & \multicolumn{2}{|c|}{ Availability $\left(\mathrm{g} / \mathrm{m}^{2}\right)$} \\
\hline & & LD & $\mathrm{HD}$ & $\mathrm{LD}$ & HD & $\mathrm{LD}$ & HD \\
\hline \multicolumn{8}{|l|}{ Leaves, stems, and grain } \\
\hline Acer spicatum & Leaf & 26.9 & 0.6 & 30.4 & 4.8 & 19.0 & $<0.1$ \\
\hline Fungi & Mushroom & 14.7 & 16.4 & 26.1 & 20.6 & $<0.1$ & $<0.1$ \\
\hline Botrychium sp. & Forb & 7.2 & 0 & 4.3 & 0 & & \\
\hline Clintonia borealis & Forb & 6.2 & 0.1 & 34.8 & 1.6 & 2.7 & 0.1 \\
\hline Maianthemum canadense & Forb & 5.9 & 1.5 & 47.8 & 15.9 & 5.1 & 0.2 \\
\hline Sorbus americana & Leaf & 4.4 & 0 & 26.1 & 0 & $<0.1$ & \\
\hline Fraxinus nigra & Leaf & 4.0 & 0 & 4.3 & 0 & & \\
\hline Epilobium angustifolium & Forb & 3.6 & 0 & 21.7 & 0 & 0.8 & \\
\hline Prunus virginiana & Leaf & 3.6 & 8.9 & 21.7 & 28.6 & $<0.1$ & $<0.1$ \\
\hline Prunus pennsylvanica & Leaf & 2.9 & 0.9 & 26.1 & 4.8 & $<0.1$ & \\
\hline Trillium sp. & Forb & 2.3 & 0.2 & 13.0 & 6.3 & $<0.1$ & $<0.1$ \\
\hline Aralia nudicaulis & Forb & 2.3 & 2.1 & 8.7 & 6.3 & 2.3 & $<0.1$ \\
\hline Acer rubrum & Leaf & 1.9 & 10.3 & 21.7 & 41.3 & 2.6 & 0.1 \\
\hline Taraxacum officinale & Forb & 1.9 & 2.2 & 13.0 & 12.7 & 0.9 & 0.2 \\
\hline Populus tremuloides & Leaf & 1.7 & 1.7 & 13.0 & 9.5 & 4.3 & 0.1 \\
\hline Graminae & Grass & 1.5 & 8.4 & 43.5 & 76.2 & 2.0 & \\
\hline Acer saccharum & Leaf & 1.3 & 6.6 & 13.0 & 14.3 & 1.6 & $<0.1$ \\
\hline Taxus canadensis & Leaf & 1.3 & $<0.1$ & 4.3 & 1.6 & & \\
\hline Salix sp. & Leaf & 1.1 & 0.5 & 8.7 & 4.8 & $<0.1$ & \\
\hline Solidago sp. & Forb & 0 & 1.2 & 0 & 4.8 & & \\
\hline Fragaria sp. & Forb & 0 & 1.5 & 0 & 19.0 & & 0.1 \\
\hline Lotus corniculatus & Farm crop & 0 & 1.6 & 0 & 1.6 & & \\
\hline Prunus serotina & Leaf & 0 & 1.9 & 0 & 11.1 & & 0.3 \\
\hline Sonchus sp. & Forb & 0.2 & 1.9 & 4.3 & 3.2 & & $<0.1$ \\
\hline Rubus sp. & Leaf & 0.7 & 2.3 & 8.7 & 27.0 & & \\
\hline Potemogeton sp. & Forb & 0 & 3.0 & 0 & 3.2 & & \\
\hline Malus pumila & Leaf & 0 & 3.2 & 0 & 6.3 & & \\
\hline Zea mays & Farm crop & 0 & 3.6 & 0 & 7.9 & & \\
\hline Medicago sativa & Farm crop & 0 & 3.8 & 0 & 7.9 & & \\
\hline Trifolium sp. & Farm crop & 0.1 & 4.8 & 4.3 & 20.6 & & \\
\hline \multicolumn{8}{|l|}{ Fruits } \\
\hline Malus pumila & Fruit & 100 & 90.1 & 4.3 & 36.5 & $<0.1$ & $<0.1$ \\
\hline Quercus sp. & Fruit & 0 & 3.6 & 0 & 1.6 & & \\
\hline Fragaria sp. & Farm crop & 0 & 3.1 & 0 & 1.6 & & \\
\hline Crataegus sp. & Fruit & 0 & 2.2 & 0 & 6.3 & & \\
\hline
\end{tabular}

Skinner and Telfer 1974). Apple trees and oak are absent from forests in LD. We assumed that apples found in one LD sample came from baits set by hunters. Baiting was also common in HD, but we think that apples ingested by deer in this region primarily originated from uncultivated apple trees growing in young forests based on the fact that most specimens found in rumens were smaller than commercial apples.

Mushrooms were a common food item in both study areas. Like apples, but to a lesser extent, their shape and size may have exaggerated their relative importance on a volumetric basis. Their frequent occurrence in rumens indicates that they represented a common food item for White-tailed Deer. Mushrooms were consumed mostly in spring in HD and in fall in LD, which may be explained by different seasonal availability or by the possibility that White-tailed Deer feed on them when preferred foods are rare at both ends of the growing season. Many studies reported large amounts of mush- rooms in White-tailed Deer diet (Crawford 1982; Johnson et al. 1995; Korschgen et al. 1980; McCaffery et al. 1974), but nobody has yet considered the potential impact of deer herbivory on mushrooms.

Diet quality - LD deer had access to a greater biomass of preferred forage (Rouleau et al. 2002a) and consumed more forbs and leaves of shrubs and trees than HD deer, which compensated by ingesting farm crops, grasses and fruits. Different forage intake resulted in a diet containing more cell solubles and lignin in LD than in HD deer. Rumen contents did not differ with respect to phenolics, which may have reflected the complex nature of the chemical group (Robbins 1993: 253). Protein content followed a similar trend as that for cell solubles, although the difference between LD and HD was small and non-significant. Between May and September, cell solubles were $8 \%$ greater in LD than HD rumens. Cell solubles, which are composed of sugars, protein, non-protein nitrogen, lipid, organic 
TABLE 2. Mean (SE; $\mathrm{n}$ ) content (\%) of cell solubles, lignin, phenolics, and nitrogen in White-tailed Deer rumen samples collected in a high-density (HD) and a low-density (LD) study area of southern Québec during the growing seasons of 1997 and 1998.

\begin{tabular}{|c|c|c|c|c|c|c|}
\hline & \multicolumn{2}{|c|}{ May-June } & \multicolumn{2}{|c|}{ July-August } & \multicolumn{2}{|c|}{ September-October } \\
\hline & HD & LD & HD & LD & $\mathrm{HD}$ & LD \\
\hline Cell solubles & $\begin{array}{c}32.4 \\
(1.4 ; 21)\end{array}$ & $\begin{array}{c}40.7 \\
(2.0 ; 14)\end{array}$ & $\begin{array}{c}34.1 \\
(1.8 ; 11)\end{array}$ & $\begin{array}{c}42.7 \\
(2.1 ; 4)\end{array}$ & $\begin{array}{c}40.7 \\
(1.5 ; 23)\end{array}$ & $\begin{array}{c}39.9 \\
(2.5 ; 2)\end{array}$ \\
\hline Lignin & $\begin{array}{c}22.2 \\
(1.0 ; 21)\end{array}$ & $\begin{array}{c}23.3 \\
(1.2 ; 14)\end{array}$ & $\begin{array}{c}21.9 \\
(1.4 ; 11)\end{array}$ & $\begin{array}{c}23.4 \\
(2.3 ; 4)\end{array}$ & $\begin{array}{c}17.8 \\
(1.0 ; 23)\end{array}$ & $\begin{array}{c}24.0 \\
(3.3 ; 2)\end{array}$ \\
\hline Phenolics & $\begin{array}{c}3.5 \\
(0.1 ; 16)\end{array}$ & $\begin{array}{c}3.6 \\
(0.2 ; 13)\end{array}$ & $\begin{array}{c}3.4 \\
(0.2 ; 7)\end{array}$ & $\begin{array}{c}3.5 \\
(0.3 ; 4)\end{array}$ & $\begin{array}{c}2.4 \\
(0.1 ; 16)\end{array}$ & $\begin{array}{c}2.7 \\
(0.4 ; 2)\end{array}$ \\
\hline Nitrogen & $\begin{array}{c}7.2 \\
(0.3 ; 16)\end{array}$ & $\begin{array}{c}7.0 \\
(0.3 ; 13)\end{array}$ & $\begin{array}{c}6.8 \\
(0.4 ; 7)\end{array}$ & $\begin{array}{c}6.5 \\
(0.6 ; 4)\end{array}$ & $\begin{array}{c}6.9 \\
(0.3 ; 16)\end{array}$ & $\begin{array}{c}7.0 \\
(0.8 ; 2)\end{array}$ \\
\hline
\end{tabular}

acid and soluble minerals (Iason and Van Wieren 1999), are highly and rapidly digestible, whereas cell walls (1cell solubles) are only partly digestible and necessitate some retention in the rumen for microbes to degrade them (Iason and Van Wieren 1999). LD does benefited therefore from a richer diet than HD counterparts during the end of gestation and peak lactation, a period with elevated energy demand in cervids (Mauget et al. 1997). In late summer, the high consumption of apples, which contain little fiber (Robbins 1993), can explain the improved quality of rumen contents in HD. The higher concentration of lignin in LD than in HD rumens likely came from the greater consumption of farm crops and grasses in the latter area, which have a lower level of lignin than natural forages do (Robbins et al. 1987).

The difference in forage quality likely reduced the growth and condition of White-tailed Deer in HD, where strong competition for forage has prevailed. Deer density in HD increased by 10 fold since the late 1970s, whereas it remained relatively low and stable in LD (Lesage et al. 2001). Deer had the same size in both study areas before 1987 (Potvin 1989), but their body mass progressively decreased in HD (Lesage et al. 2001; Potvin 1994*). At the time of our study, the eviscerated carcass mass of fully grown male deer averaged $80 \mathrm{vs.} 116 \mathrm{~kg}$ in HD and LD, respectively (Lesage et al. 2001). Additional measurements throughout the deer range in Québec revealed that deer size began to decline when forage competition intensified in summer; i.e., forage availability $<10000 \mathrm{~kg} /$ deer (Boucher 2004). Our results concur with the hypothesis that rural deer living at high density cannot fully compensate for the rarity of natural forage in woodlots during summer by consuming cultivated plants (Rouleau et al 2002a). All of these studies suggest that deer populations have reached excessive densities in HD.

\section{Acknowledgments}

We thank R. Bélanger, J. Boisvert, B. Deschamps, and M. Desrochers from Transports Québec, who kindly gave us access to deer carcasses. J. Bachand, C. Bélanger, M. Bélanger, N. Bergeron and E. Jeanson helped in collecting the rumen samples. We are grateful to $\mathrm{G}$. Picard for conducting the chemical analysis, to
N. Desrosiers, and É. Normand for their assistance in the laboratory, and to C. Roy for helping with plant identification. G. Daigle, from the Service de consultation statistique, Université Laval, did the statistical analysis.

\section{Documents Cited (marked * in text)}

Dicaire, A. 1999. Analyse et interprétation des résultats de la saison de chasse au cerf de Virginie 1997 dans la zone 5. Pages 100-102 in Compte rendu de l'atelier sur la grande faune 1998. Edited by C. Daigle. Ministère de l'Environnement et de la Faune du Québec, direction de la faune et des habitats.

Guérard, Y., and J. Legris. 1984. Le parc Yamaska et sa végétation (Québec). Unpublished report, Université du Québec à Montréal. 337 pages.

Gosselin, M.-J. 1994. Plan de gestion du cerf de Virginie au Québec 1995-1999, zone 5. Ministère de l'Environnement et de la Faune du Québec. Report \# 94-2502-5-11. 8 pages.

Lamoureux J. 1994. Plan de gestion du cerf de Virginie au Québec 1995-1999, zone 2. Ministère de l'Environnement et de la Faune du Québec. Report \# 94-2502-2-11. 6 pages.

Lamoureux, J., and A. Pelletier. 2000. Analyse et interprétation des résultats de la saison de chasse au cerf de Virginie 1997 dans la zone 2. Pages 65-68 in Compte rendu de l'atelier sur la grande faune 1999 et bilan de la récolte des grands gibiers 1998-1999. Edited by C. Daigle. Société de la faune et des parcs du Québec, direction de la faune et des habitats.

Potvin, F. 1994. Condition physique des cerfs mâles de 1, 5 an de 1973 à 1992 dans les zones 5, 10 et 11. Pages 45-47 in Compte rendu du onzième atelier sur la grande faune. Edited by C. Daigle. Ministère de l'Environnement et de la Faune du Québec. Report \# 94-2420-06.

Rowe, J. S. 1972. Les régions forestières du Canada. Ministère de l'Environnement, service canadien des forêts. Report \# 1300F.

Wilson, C. V. 1971. The climate of Québec. Part one. Climatic atlas. Canadian Meteorological Service. 84 pages.

\section{Literature Cited}

Ashley, P. E., G. B. McCullough, and J. T. Robinson. 1995. Morphological responses of white-tailed deer to a severe population reduction. Canadian Journal of Zoology 76: $1-5$.

Balgooyen, C. P., and D. M. Waller. 1995. The use of Clintonia borealis and other indicators to gauge impacts of White-tailed Deer on plant communities in Northern Wisconsin. Natural Areas Journal 15: 308-318. 
Boucher, S., M. Crête, J. P. Ouellet, C. Daigle, and L. Lesage. 2004. Large-scale trophic interactions: Whitetailed deer growth and forest understory. Écoscience 11: 286-295.

Chamrad, A. D., and T. W. Box. 1964. A point frame for sampling rumen contents. Journal of Wildlife Management 28: 473-477.

Crawford, H. S. 1982. Seasonal food selection and digestibility by tame white-tailed deer in central Maine. Journal of Wildlife Management 46: 974-982.

Crête, M., J. Huot, and L. Gauthier. 1990. Food selection during early lactation by caribou calving on the tundra in Québec. Arctic 43: 60-65.

Crête, M, J. Huot, R. Nault, and R. Patenaude. 1993. Reproduction, growth and body composition of Rivière George caribou in captivity. Arctic 46: 189-196.

Crête M., J.-P. Ouellet, and L. Lesage. 2001. Comparative effects on plants of caribou/reindeer, moose and whitetailed deer herbivory. Arctic 54: 407-417.

Dumont, A., M. Crête, J.-P. Ouellet, J. Huot, and J. Lamoureux. 2000. Population dynamics of northern whitetailed deer during a series of mild winters: evidence of regulation by food competition in winter. Canadian Journal of Zoology 78: 764-776.

Gauthier, L., R. Nault, and M. Crête. 1989. Variations saisonnières du régime alimentaire des caribous du troupeau de la rivière George, Québec nordique. Le Naturaliste canadien (Québec). 116: 101-112.

Goering, H. K., and P. J. Van Soest. 1970. Forage fiber analyses. USDA Handbook 379.

Healy, W. M. 1971. Forage preferences of tame deer in a northwest Pennsylvania clear-cutting. Journal of Wildlife Management 35: 717-723.

Hjeljord, O., and T. Histol. 1999. Range-body mass interaction of a northern ungulate - a test of hypothesis. Oecologia 119: 326-339.

Iason, G. R., and S. E. Van Wieren. 1999. Digestive and ingestive adaptations of mammalian herbivores to lowquality forage. Pages 337-369 in Herbivores: between plants and predators. Edited by H. Olff, V. K. Brown, and R. H. Drent. Blackwell Science Publications, Osney Mead.

Johnson, A. S., P. E. Hale, W. M. Ford, J. M. Wentworth, J. R. French, O. F. Anderson, and G. B. Pullen. 1995. White-tailed deer foraging in relation to successional stage, overstory type and management of southern Appalachian forests. American Midland Naturalist 133: 18-35.

Kie, J. G., and R. T. Bowyer. 1999. Sexual segregation in white-tailed deer: density-dependant changes in use of space, habitat selection and dietary niche. Journal of Mammalogy 80: 1004-1020.

Korschgen, L. J., W. R. Porath, and O. Torgerson. 1980. Spring and summer foods of deer in the Missouri Ozarks. Journal of Wildlife Management 44: 89-97.

Lesage, L., M. Crête, J. Huot, and J-P. Ouellet. 2000. Quality of plant species utilized by northern white-tailed deer in summer along a climatic gradient. Écoscience 7: 439-451.

Lesage, L., M. Crête, J. Huot, and J-P. Ouellet. 2001. Evidence of trade-off between growth and body reserves in northern white-tailed deer. Oecologia 126: 30-41.
Lesage, L., M. Crête, J. Huot, and J-P. Ouellet. 2002. Use of forest maps versus field surveys to measure summer habitat selection and sexual segregation in northern whitetailed deer. Canadian Journal of Zoology 80: 717-726.

Marigo, G. 1973. Sur une méthode de fractionnement et d'estimation des composés phénoliques chez les végétaux. Analysis 2: 106-110.

Mauget, C., R. Mauget, and A. Sempéré. 1997. Metabolic rate in female European roe deer (Capreolus capreolus): incidence of reproduction. Canadian Journal of Zoology 75: 731-739.

McCaffery, K. R., J. Tranetzki, and J. Piechura Jr. 1974. Summer food of deer in northern Wisconsin. Journal of Wildlife Management 38: 215-219.

McCullough, D. R. 1985. Variables influencing food habits of white-tailed deer on the George Reserve. Journal of Mammalogy 66: 682-692.

Mould, E. D., and C. T. Robbins. 1982. Digestive capabilities in elk compared to White-Tailed Deer. Journal of Wildlife Management 46: 22-29.

Nixon, C. M., L. P. Hansen, P. A. Brewer, and J. E. Chelsvig. 1991. Ecology of white-tailed deer in an intensively farmed region of Illinois. Wildlife Monographs 118: 1-77.

Potvin, F. 1989. Morphologie du cerf de Virginie au Québec: variations régionales et annuelles. Naturaliste Canadien (Québec) 116: 87-100.

Potvin, F., L. Breton, L.-P. Rivest, and A. Gingras. 1992. Application of a double-count survey technique for whitetailed deer, Odocoileus virginianus, on Anticosti Island, Québec. Canadian Field-Naturalist 106: 435-442.

Robbins, C. T. 1993 . Wildlife feeding and nutrition, $2^{\text {nd }}$ edition. Academic Press, San Diego. 352 pages.

Robbins, C. T., S. Mole, A. E. Hagerman, and T. A. Hanley. 1987. Role of tannins in defending plants against ruminants: reduction in dry matter digestion? Ecology 68: 1606-1615.

Rouleau, I., M. Crête, and J.-P. Ouellet. 2002a. Contrasting the summer ecology of White-tailed Deer inhabiting a forest and a rural landscape. Écoscience 9: 459-469.

Rouleau, I., M. Crête, G. Daigle, and P. Etchevary. 2002b. Rapid estimation of plant biomass used as forage or cover by White-tailed Deer, Odocoileus virginianus, and Snowshoe Hare, Lepus americanus, in mixed and coniferous forest of southeastern Québec. The Canadian Field-Naturalist 116: 523-528.

SAS Institute Inc. 1988. SAS/STAT User's guide. SAS Institute Inc. Cary, North Carolina

Sauvesty, A. F., F. Page, and J. Huot. 1991. A simple method for extracting plant phenolic compounds. Canadian Journal of Forest Research 22: 654-659.

Short, H. L. 1971. Forage digestibility and diet of deer on southern upland range. Journal of Wildlife Management 35: 698-706.

Skinner, W. R., and E. S. Telfer. 1974. Spring, summer, and fall foods of deer in New Brunswick. Journal of Wildlife Management 38: 210-214.

Waller, D. M., and W. S. Alverson. 1997. The white-tailed deer: a keystone herbivore. Wildlife Society Bulletin 25: 217-226.

Received 31 March 2003

Accepted 1 November 2004 